\title{
Protocol for disease-oriented Russian disc degeneration study (RuDDS) biobank facilitating functional omics studies of lumbar disc degeneration
}

Olga N. Leonova ${ }^{1}$, Elizaveta E. Elgaeva ${ }^{2,3}$, Tatiana S. Golubeva $^{3}$, Alexey V. Peleganchuk ${ }^{1}$, Aleksandr V. Krutko $^{4}$, Yurii S. Aulchenko ${ }^{2,3^{\wedge}}$, Yakov A. Tsepilov ${ }^{2,3^{\wedge}}$

1 Novosibirsk Research Institute of Traumatology and Orthopedics, Novosibirsk, Russia

2 Novosibirsk State University, Novosibirsk, Russia

3 Institute of Cytology and Genetics, Novosibirsk, Russia

4 Priorov National Medical Research Center of Traumatology and Orthopedics, Moscow, Russia

Corresponding author: Olga Leonova, MD, PhD, Neurosurgery Department, Novosibirsk Research Institute of Traumatology and Orthopaedics (NRITO) n.a.Ya.L.Tsivyan, Frunze str, 17, Novosibirsk, Russia, onleonova@gmail.com

Keywords: lumbar disc degeneration; biobank; lumbar spine; functional genomics; transcriptomics; glycomics.

\section{Authors and Institutions:}

Olga Leonova, MD, PhD, Neurosurgery Department, Novosibirsk Research Institute of Traumatology and Orthopaedics (NRITO) n.a.Ya.L.Tsivyan, Frunze str, 17, Novosibirsk, Russia, ORCID 0000-00029916-3947;

Elizaveta E. Elgaeva, MSc, Novosibirsk State University, Novosibirsk, Russia, Institute of Cytology and Genetics, Novosibirsk, Russia, ORCID 0000-0002-2484-553X

Tatiana S. Golubeva, PhD, Institute of Cytology and Genetics, Novosibirsk, Russia, ORCID 0000-00024400-0665

Alexey V. Peleganchuk, MD, PhD, Neurosurgery Department, Novosibirsk Research Institute of Traumatology and Orthopaedics (NRITO) n.a.Ya.L.Tsivyan, Frunze str, 17, Novosibirsk, Russia, ORCID 0000-0002-4588-428X

Aleksandr Krutko, MD, PhD, Neurosurgery Department, Priorov National Medical Research Center of Traumatology and Orthopedics, Priorova str, 10, Moscow, Russia, ORCID 0000-0002-2570-3066

Yurii S. Aulchenko^, Novosibirsk State University, Novosibirsk, Russia, Institute of Cytology and Genetics, Novosibirsk, Russia

Yakov A. Tsepilov^, Novosibirsk State University, Novosibirsk, Russia, Institute of Cytology and Genetics, Novosibirsk, Russia

${ }^{\wedge}$ contributed equally to this work 
medRxiv preprint doi: https://doi.org/10.1101/2021.03.07.21253070; this version posted March 9, 2021. The copyright holder for this preprint (which was not certified by peer review) is the author/funder, who has granted medRxiv a license to display the preprint in perpetuity.

It is made available under a CC-BY-NC-ND 4.0 International license.

\section{ABSTRACT}

\section{Introduction}

Lumbar intervertebral disc degeneration (DD) disease is one of the main risk factors for low back pain. The social and economic importance of low back pain is very high: back pain is among the leading causes of absenteeism and the cost of treating back pain exceeds the cost of treatment of many other serious diseases (cancer, in particular); however, therapy does not always provide the desired result. Despite the variability of biological studies of lumbar DD, it is still not fully understood, partially due to the fact that there are only few studies using systematic and integrative approaches. Hence, more integrative omics studies are needed to link all pieces of knowledge together, build a complete picture of biology of lumbar DD and obtain a deeper understanding of the processes underlying this pathology.

\section{Methods and analysis}

This disease-oriented biobank to study lumbar disc degeneration will be recruited from two clinical centers. A total of 1100 participants with available lumbar MRI will be enrolled during the three-year period. General information about a patient, medical history, lumbar MRI parameters and biological material (whole blood and plasma) will be collected in the centers at baseline. Then, from those patients, who will undergo a spine surgery during the treatment, disc tissue samples will be gained. Eventually, postoperative clinical data will be collected from operated patients during the follow-up.

\section{Ethics and dissemination}

The study will be performed according to the Helsinki Declaration. The study protocol was approved by the Local Ethical Committee of NRITO (№034/20 dated 02 Oct 2020) and by the Local Ethical Committee of Priorov CITO (№1/21 dated 25 Feb 2021). Preliminary and final results will be presented in peer-reviewed journals, at national and international congresses.

\section{Trial registration number NCT04600544}

\section{ARTICLE SUMMARY}

\section{STRENGTHS AND LIMITATIONS OF THIS STUDY}

- Two-center and multiple-discipline study: the study includes two centers (Moscow in the European and Novosibirsk in the Asian part of Russia), with research teams specializing in following fields: (1) clinical aspects of lumbar disc degeneration disease, (2) biology and genetics of pain, (3) generation of omics data and (4) multi-omics data analysis

- Collection of variable biological material: whole blood, plasma and, for part of the participants, intraoperative material of the lumbar disc (with different DD status) will be available for omics studies

- Objective diagnosis: lumbar DD status is confirmed by MRI, not self-reported diagnosis

- Sample size is limited compared to nationwide biobanks

- Patients with severe lumbar DD status will be more prevalent in the biobank than these with mild or no lumbar DD compared to the general population 
medRxiv preprint doi: https://doi.org/10.1101/2021.03.07.21253070; this version posted March 9, 2021. The copyright holder for this preprint (which was not certified by peer review) is the author/funder, who has granted medRxiv a license to display the preprint in perpetuity.

It is made available under a CC-BY-NC-ND 4.0 International license.

\section{INTRODUCTION}

Intervertebral disc degeneration is a normal aging process, but in some cases it causes lumbar disc degeneration disease (LDDD) [1,2]. Intervertebral disc degeneration (DD) often begins earlier than degenerative changes in the ligaments, cartilages and other tissues of spinal segment [3]. DD is a major contributor to low back pain [4], but also DD can proceed without back pain [5-8]. However, LDDD is associated with lower health-related quality of life [9] and is the leading cause of population absenteeism and disability $[10,11]$.

The prevalence of lumbar DD in the general population is extremely high: up to $50 \%$ in people of 30 39 years old [2,12]. There is not a single adult without even a small degree of degeneration in the intervertebral discs [13].

List of well-known risk factors of LDDD includes female gender, advanced age [14], obesity, smoking [15], absence of or extreme physical activity [16] and genetic risk factors [17]. However, even in the absence of obvious risk factors, there are cases of LDDD among young people [1,14], as well as progressive severe LDDD requiring a number of surgical interventions.

Biology of intervertebral DD is actively studied from different points of view. Besides various studies of degenerative disc morphology [18-22] and molecular biology [16,23-25] there is an increasing number of genetic [26,27], transcriptomic [28-30] and proteomic [31-33] studies of intervertebral DD. Thus, nowadays based on candidate-gene [34] and genome-wide associated studies (GWAS) [35,36] over 160 genes were considered as potentially involved in intervertebral disc degeneration, although less than ten of them provide strong evidence for the association [34]. More than 500 genes were highlighted as differentially expressed in degenerative disc tissue in comparison with healthy intervertebral discs [37,38]. Moreover, proteomic [31-33] and metabolomics [39] changes were also detected in degenerative intervertebral discs. However, despite a large number of studies of LDDD, it is still not fully understood, partially due to the fact that there are only few studies using systematic and integrative approaches [40]. Hence, more integrative omics studies are needed to link all pieces of knowledge together, build a complete picture of biology of lumbar DD and obtain a deeper understanding of the processes underlying this pathology.

\section{Research aim and objectives}

The main aim of this study is to establish disease-oriented biobank to facilitate research in biology of the lumbar disc degeneration. Diverse biological samples (whole blood, plasma, disc tissue) along with MRI imaging, clinical, socio-demographic and various omics data (e.g. genomic and transcriptomic) will be available for researchers and clinicians for a variety of further multi-omics studies. It will lay the groundwork for the development of early diagnostics of DDD and its personalized treatment.

\section{METHODS AND ANALYSIS}

\section{Patient and Public Involvement}

Patients and/or the public were not involved in the design, or conduct, or reporting, or dissemination plans of this research.

\section{Study design and settings}


medRxiv preprint doi: https://doi.org/10.1101/2021.03.07.21253070; this version posted March 9, 2021. The copyright holder for this preprint (which was not certified by peer review) is the author/funder, who has granted medRxiv a license to display the preprint in perpetuity.

It is made available under a CC-BY-NC-ND 4.0 International license .

This disease-oriented biobank to study lumbar disc degeneration will be recruited from two centers: Priorov National Medical Research Center of Traumatology and Orthopedics (Priorov CITO), Moscow, Russia and Novosibirsk Research Institute of Traumatology and Orthopedics (NRITO), Novosibirsk, Russia. It will include only patients with available MRI of the lumbar spine, who signed the informed consent. Clinical data and specimen collection will be performed in three visits as described in Table 1. At the first step general information about a patient, his medical history and MRI scans of lumbar spine will be obtained. Patient's biological material (whole blood and plasma) will be also sampled in the centers at baseline. Then, from those patients, who will undergo a spine surgery during the treatment, disc tissue samples will be gained. Eventually, postoperative clinical data will be collected from operated patients during the follow-up. During three years, we expect to collect information and biological material from a total of 1100 . The full scheme of the study is presented at Figure 1.
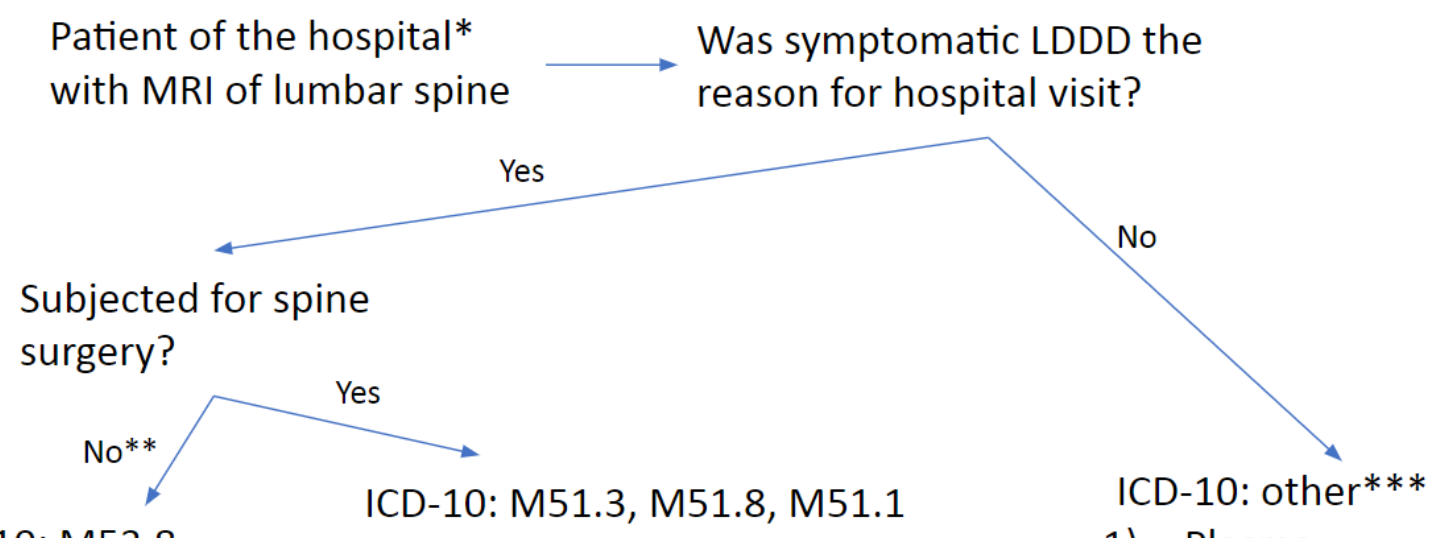

ICD-10: M53.8
1) Plasma
2) Blood
3) Questionnaire

Expected N - 500
1) Plasma

2) Blood

3) Questionnaire

4) Interoperational disc material Expected N - 500
1) Plasma

2) Blood

3) Questionnaire Expected N - 100
After 3 month after surgery
1) Questionnaire Expected $\mathrm{N}-80 \%$ from the previous step

Figure 1. Patient selection. Sample size is depicted for 3 years timeline of project duration. Expected total sample size is $1100 .{ }^{*}$ Novosibirsk Research Institute of Traumatology and Orthopedics (NRITO) / Priorov National Medical Research Center of Traumatology and Orthopedics (Priorov CITO). ${ }^{* *}$ Conservative treatment. ${ }^{* * *} \mathrm{ICD}-10: 171$ Aortic aneurysm and dissection, K81 Cholecystitis, K85 Pancreatitis, K25, K26 Penetrating ulcer, M06.4 Inflammatory polyarthropathy, N00-N99 Diseases of the genitourinary system

\section{Table 1. Scheduled procedures for clinical data and samples collection.}


medRxiv preprint doi: https://doi.org/10.1101/2021.03.07.21253070; this version posted March 9, 2021. The copyright holder for this preprint (which was not certified by peer review) is the author/funder, who has granted medRxiv a license to display the preprint in perpetuity.

It is made available under a CC-BY-NC-ND 4.0 International license .

\begin{tabular}{|c|c|c|c|}
\hline & Visit 1 - Baseline & $\begin{array}{l}\text { Visit } 2 \text { - Day of } \\
\text { surgery }^{1}\end{array}$ & $\begin{array}{ll}\text { Visit } 3 & -3 \\
\text { months } & \text { after } \\
\text { surgery }^{2} & \end{array}$ \\
\hline Visit Window ( \pm Days) & & & Day $90 \pm 14$ days \\
\hline Informed Consent & $\mathrm{X}$ & & \\
\hline Eligibility Criteria & $\mathrm{X}$ & & \\
\hline Medical History & $\mathrm{X}$ & & \\
\hline Anamnesis Vitae & $\mathrm{x}$ & & \\
\hline Demographics & $\mathrm{X}$ & & \\
\hline Blood samples & $\mathrm{X}$ & & \\
\hline MRI & $\mathrm{X}$ & & \\
\hline $\mathrm{ODI}^{3}$ & $\mathrm{X}$ & & $x$ \\
\hline VAS $^{4}$ & $x$ & & $x$ \\
\hline Indications for surgery & & $x$ & \\
\hline Surgical Procedure & & $\mathrm{x}$ & \\
\hline $\begin{array}{l}\text { Intervertebral disc } \\
\text { samples }\end{array}$ & & $x$ & \\
\hline $\begin{array}{l}\text { Adverse events / Serious } \\
\text { adverse events }\end{array}$ & $\mathrm{X}$ & $x$ & $x$ \\
\hline
\end{tabular}

${ }^{1}$ only for patients subjected for surgery, ${ }^{2}$ optional, ${ }^{3}$ Oswestry Disability Index (ODI) scale, ${ }^{4}$ Visual analogue scale (VAS) for back and leg pain.

All biological samples from NRITO will be then transported to the Institute of Cytology and Genetics (ICG), Novosibirsk, Russia for long-term storage, further processing and omics profiling, including genotyping of blood samples and RNA-Sequencing of disc tissue. Priorov CITO will store the specimens on its own.

\section{Patient selection}

140 Participants aged over 18 with available MRI scans of lumbar spine, who will also sign an informed consent and meet all the eligibility criteria (Table 2), will be included in the study. All participants will be grouped by three groups based on their diagnosis and type of treatment (conservative or surgical). All details and ICD-10 codes required for inclusion are presented in Figure 1. Restrictions on participation in the study for patients with bloodborne pathogens is determined by requirements of laboratory biosafety.

We plan to collect whole blood and plasma samples from two centers no less than 1100 patients (see Figure 1). The SNP array based whole-genome genotyping and total plasma protein $\mathrm{N}$-glycosylation profiles will be measured for at least 384 participants. Expression profiles of approximately 40 disc specimens will be measured.

Table 2. Eligibility criteria.

\begin{tabular}{|l|l|}
\hline Inclusion criteria & Exclusion criteria \\
\hline 1. Age over 18; & $\begin{array}{l}\text { 1. Any contraindication or inability to undergo baseline } \\
\text { 2. Presence of lumbar MRI scans; }\end{array}$ \\
\hline
\end{tabular}


3. Signed informed consent for voluntary participation is provided.
2. Prior surgeries at any level of the lumbar spine;

3. Other non-degenerative spinal conditions that may have an impact on subject safety, wellbeing or the intent and conduction of the study;

4. History or presence of HIV, hepatitis B, hepatitis C.

\section{MRI imaging, clinical and socio-demographic data}

We require each patient from this study to have lumbar spine MRI images. MRI scanning will be performed on a 1.5 Tesla (or higher) tomograph and will include L1-S1 lumbar segments. T1 and T2 weighted images, acquired both in the axial and sagittal planes, will be obtained. Images will be used to assess the disc degeneration grade, presence and type of Modic changes and presence and severity of vertebral endplate defects. Disc degeneration grade will be estimated under the Pfirrmann classification from 1 to 5 , with 1 corresponding to normal disc and 5 corresponding to the most severe degeneration [41]. Modic changes will be evaluated for each endplate (from the lower L1 vertebra to the upper S1 vertebra) on sagittal scans using T1WI and T2WI [42]. Vertebral endplate defects will be ranged from 1 to 6 according to the Rajasekaran classification [43]. Then, total endplate scores (TEPS) will be calculated as the sum of the endplate defect scores of both upper and lower endplates in each L1-S1 spinal segment. Additionally, height of the intervertebral discs and severity of osteophytes will be estimated based on Jarosz classification [44].

Clinical assessment will include demographic data (sex, age), self-reported ethnicity, height, weight, family status, physical activity, smoking, comorbidity, education level and job type.

All participants will also complete the following clinical questionnaires: visual analogue scale (VAS) [45] back and VAS leg estimating the intensity of back and leg pain correspondingly and the Oswestry disability index (ODI) $[46,47]$ questionnaire.

\section{Sample collection, transporting and storing}

Samples, collected from NRITO will be frozen at $-40 \mathrm{C}$ (whole blood and plasma) or at $-80 \mathrm{C}$ (disc samples) and then transferred to ICG for long-time storage at -80C. All biosamples from Priorov CITO will be frozen and stored on-site at $-80 \mathrm{C}$.

Blood and plasma sampling: from each patient $13 \mathrm{ml}$ of peripheral venous blood will be collected into two BD Vacutainer $4 \mathrm{ml}$ and $9 \mathrm{ml} \mathrm{K2}$ EDTA tubes (or three $4 \mathrm{ml}$ K2 EDTA tubes depending on availability). Tubes will be labeled with a unique patient's code. During the first 30 min after blood collection, the $4 \mathrm{ml}$ vacutainer with whole blood will be placed into the test tube rack and transported to the freezer to be stored at $-40 \mathrm{C}$. The other $9 \mathrm{ml}$ blood tube will be used for plasma extraction according to the plasma extraction protocol (see Supplementary Materials 1). When the plasma will have been extracted, the tubes with plasma will also be labeled and placed into the freezer at $-40 \mathrm{C}$.

Eventually, all the tubes from NRITO will be transported to ICG in thermoboxes with cooling agents and then placed into freezers at $-80 \mathrm{C}$. Samples from Priorov CITO will be stored locally at $-80 \mathrm{C}$ at once.

Plasma samples could be potentially used for cell-free DNA, glycomics, proteomics and metabolomics analyses.

Disc sampling: during the surgical procedure the resected fragments of intervertebral discs will be placed into sterile falcon $50 \mathrm{ml}$ tubes that will be stored in the operating room till the end of 
medRxiv preprint doi: https://doi.org/10.1101/2021.03.07.21253070; this version posted March 9, 2021. The copyright holder for this preprint (which was not certified by peer review) is the author/funder, who has granted medRxiv a license to display the preprint in perpetuity.

It is made available under a CC-BY-NC-ND 4.0 International license.

intervention (no longer than $40 \mathrm{~min}$ ). The falcons will be labeled with unique codes and will be transported to the laboratory in 5 min where the discs' fragments will be put into liquid nitrogen.

Disc samples from NRITO will be transferred to ICG within thermoses with liquid nitrogen and then will be stored in freezers at $-80 \mathrm{C}$. Biospecimens obtained in Priorov CITO will be stored on the spot at $-80 \mathrm{C}$.

\section{Genotyping}

DNA will be extracted according to the standard protocol with the help of Qiagen DNeasy Blood \& Tissue Kit. Genotyping by at least 600,000 SNPs will be performed using whole-genome SNP-arrays of high coverage (tentatively, Illumina Infinium Global Screening Array will be used). Imputation procedure will be carried out using Haplotype Reference Consortium [48] or later reference panel.

\section{Total plasma proteins $\mathrm{N}$-glycosylation profiling}

The plasma glycans profiling will be performed using APTS glycan labelling kit (Genos) according to standard protocol [49].

\section{Total RNA profiling}

The intraoperative material will be homogenized using Tissuelyzer II homogenator (QUAGEN) and total RNA will be extracted and converted to CDNA using Kit for the isolation of total RNA and microRNA from cells and tissues (Biolabmix, Russia) and M-MuLV-RH First Strand cDNA Synthesis Kit (Biolabmix, Russia) respectively. The amount of extracted RNA and its quality will be estimated using Bioanalyzer 2100 (Agilent).

Total RNA sequencing will be performed using Illumina-HiSeq 4000 under PE-protocol. The read length up to $100 \mathrm{bp}$ and sequencing coverage of $20 \mathrm{M}$ are expected. In total not less than 20 samples will be profiled.

\section{Duration of the project}

Specimens collection and processing will be lasting for three years, unless the additional funding is obtained to expand the biobank. Samples will be stored for fifteen years after collection according to the storage protocol described above.

\section{Statistical data analysis}

In this section we will describe designs of further studies that we plan to conduct based on the omics data generated from the samples of the biobank.

\section{Genome-wide association study of LDD and in-silico follow-up}

We will perform genome-wide association study (GWAS) using quantitative scales of assessed disc degeneration status. The GWAS results will be used for replication of genome-wide significant findings from GWAS of LDD conducted in 2013 by Williams et al. [35]. Further, these two sets of GWAS will be meta-analysed to obtain the largest to date GWAS on LDD for European ancestry population. The results of meta-analysis will be used for in-silico follow-up functional annotation and prioritization of genes involved in LDD development.

\section{Functional analysis and data integration}

GWAS meta-analysis results will be annotated in order to predict the probable effects of replicated SNPs on gene expression and disease development. Furthermore, we will highlight the molecular 
medRxiv preprint doi: https://doi.org/10.1101/2021.03.07.21253070; this version posted March 9, 2021. The copyright holder for this preprint (which was not certified by peer review) is the author/funder, who has granted medRxiv a license to display the preprint in perpetuity.

It is made available under a CC-BY-NC-ND 4.0 International license .

pathways, cell and tissue types most likely to be involved in DD pathogenesis. All this information will be used for gene prioritisation alongside with the results of analyses, based on colocalization analysis [50] and Mendelian randomization [51,52]. This methodology will be applied for causal inference between DD and gene expression profiles from different tissues, also including the transcriptomic data from intervertebral discs obtained in this study. A gene network of DDD regulation will be built and the key regulators will be revealed.

\section{Glycomics data analysis}

The association of plasma N-glycans levels with disc degeneration status will be studied. Any obtained data may be helpful to use as dynamic glycan biomarkers for elucidating DD pathogenesis and may ultimately provide prognostic information.

\section{Transcriptomic data analysis}

Patient group with available intraoperative disc material (see Figure 1) could be divided into "cases" or "degenerated disc" (grades 4-5 of disc degeneration according to Pfirrmann classification) and "controls" or "the healthy disc" (grades 1-3 of disc degeneration according to Pfirrmann classification) $[43,53]$.

This division doesn't influence the scheme of patient recruiting or sample collection but plays a role in the transcriptomic data analysis. The groups will include following ICD-10 codes: M51.1 "Thoracic, thoracolumbar and lumbosacral intervertebral disc disorders with radiculopathy" (cases); M51.3, M51.8 "Other thoracic, thoracolumbar and lumbosacral intervertebral disc degeneration" (controls).

Transcriptomic data obtained in this study will be used for detection of genes differentially expressed in discs between cases and controls. In short, the gene expression data will be mapped [54] on the reference genome and quality of the reads will be recalibrated ("Picard Toolkit." 2019. Broad Institute, GitHub Repository. http://broadinstitute.github.io/picard/; Broad Institute). Subsequently, aiming to reveal the transcriptomic differences in intervertebral discs tissue between cases and controls, we will count the reads and identify differentially expressed genes (DEGs) [55]. At last, the revealed DEGs will be functionally annotated with Gene Ontology terms.

The data will also be used to identify expression quantitative trait loci (eQTLs). We will perform eQTL analysis of gene expression levels in intervertebral discs using methodology described in [56]. Resulting regional association summary statistics will be used for the gene prioritization.

\section{Data management and access}

All data management and access procedures will be identical in both participating centers.

Each participant included in the study is assigned a unique code. Keys for these codes are saved in the locked storage of the internal hospital Electronic Data Capture (EDC) system, with access provided only for curators of the study. All clinical data, obtained from patients, are kept in the internal hospital EDC system, accessible only for authorized researchers filling data into it. Information on who entered the data into the clinical database is available for viewing. During the study, internal monitoring will be conducted to maintain the quality of the study in accordance with the GCP principles. Participant and specimen codes are transferred to ICG along with the specimens from both clinical centers in an anonymous way. 
medRxiv preprint doi: https://doi.org/10.1101/2021.03.07.21253070; this version posted March 9, 2021. The copyright holder for this preprint (which was not certified by peer review) is the author/funder, who has granted medRxiv a license to display the preprint in perpetuity.

It is made available under a CC-BY-NC-ND 4.0 International license .

Information on the physical location of specimens is kept with limited access only for curators of the study. Genotypes, transcriptomic data and data produced during their processing will be stored on a local server in ICG.

To access the database, omcis data and other relevant information, projects should be submitted to the steering committee (contact the corresponding author) of the RuDDS.

\section{DISCUSSION}

This study will be carried out in two different centers providing wider population coverage and more reliability to the sample storage, as data and specimens will be stored in two places. Participants will be recruited at unique medical centers (NRITO, Priorov CITO), that are the only centers in Russia specializing in studying DDD. The distinctive features of our clinical centers are: large constant flow of DDD patients, opportunity to conduct spine MRI and a highly-qualified team $[57,58]$. In the same way, our multidisciplinary research group, who will generate and analyze omics data, has a broad experience in studying back pain (one of the main manifestations of DDD) [59-61] and statistical and functional data analysis using integrative omics approaches $[62,63]$.

Another notable advantage of the present project is availability of diverse and rare biological material that can be used for multiple profiling. Besides the whole blood samples, plasma and the intervertebral disc tissue obtained during the spine surgery will be collected. Presence of variable biological specimens for the same study participants will allow conducting integrative multi-omics analyses. Thus, not only genomes, but also transcriptomes, glycomes and other '-omes' can be measured using these samples. To our knowledge it is the first study with multiple omics profiling of similar biological material. Current studies are limited by single profiling of one or two tissues [one - [32], [33]; two [37], [31], [28], [29] or use omics datasets in open access, combining data from different cohorts [40]. The importance of the multi-omics approach is hard to overestimate, as it allows us to look at the disease from different points of view and level-up our understanding of the pathology.

One more substantial strength of our study is the assessment of disc degeneration grade by MRI scans because it is the most accurate and precise method of DD diagnostics among the others. In LDD studies based on plain radiography [64] or CT [65] phenotype definition is rather subjective as these approaches provide only indirect evidence of disc degeneration such as disc height loss and osteophytes. Similarly, the use of self-reported questionnaires for LDD identification [66] is not reliable enough. On the contrary, Pfirrmann grading system of disc degeneration used in the present study is based on MRI scans and estimates the main characteristics of DD by assessing the signal intensity and height of the intervertebral disc - the more dehydrated the disc is, the more severe degenerative changes are in it [41].

However, this study has some limitations. First, it should be noted that the expected sample size is modest in comparison with national country-level biobanks or large prospective cohorts. Sample size of the present study is four times less than one reported for meta-analysis of DDD studies reported by Williams et al. [35]. This limitation is explained by funding, establishing the recruitment period of three years. Nonetheless, the expected number of disc tissue samples ( $\sim 510)$ and transcriptome profiles of them $(\sim 40)$ is comparable with other omics studies using disc specimens [proteome [33] - 7 cases / 7 controls; metabolome [39] - 60 cases / 21 controls; transcriptome [28] - 39 annulus fibrosus (AF) and 21 nucleus pulposus (NP) samples, [29] - 24 AF and 24 NP samples].

The next limitation of our study is imbalance between patients with "healthy disc" and "degenerated disc" in the group of patients subjected to surgery. Obviously, patients with "healthy discs" are 
medRxiv preprint doi: https://doi.org/10.1101/2021.03.07.21253070; this version posted March 9, 2021. The copyright holder for this preprint (which was not certified by peer review) is the author/funder, who has granted medRxiv a license to display the preprint in perpetuity.

It is made available under a CC-BY-NC-ND 4.0 International license .

subjected to spinal surgery under specific circumstances. Although, according to our protocol we still can expect some controls in this group (in total, the expected number of controls is 20). In groups not subjected to surgery we expect the ratio between cases and controls closer to the general population.

It should be noted that "healthy disc" is a conditional definition, not objective enough; however, the inter-observer agreement is quite high among different groups of researchers, therefore, Pfirrmann classification is considered to be highly reliable [67]. The main point here is that the existence of adult patients with perfectly healthy lumbar discs is questionable. To find such patients a huge large-scale exploratory study is needed. Nevertheless, according to a population-based study there are no adults with lumbar discs containing no degenerative changes [13].

\section{ETHICS AND DISSEMINATION}

The study will be performed according to the Helsinki Declaration; the study protocol was approved by the Local Ethical Committee of NRITO (№034/20 dated 02 Oct 2020) and by the Local Ethical Committee of Priorov CITO (№1/21 dated 25 Feb 2021). Preliminary and final results will be presented in peer-reviewed journals, at national and international congresses.

\section{Acknowledgements}

\section{AUTHORS' CONTRIBUTIONS}

ONL, EEE, AVK, YSA and YAT contributed to the study concept and design of the study protocol. ONL, EEE, TSG, YAT contributed to the development of specimen collection, storage and profiling protocols. ONL, AVP and AVK contributed to the setting of the logistics of working with hospitals and ethical committee approval. ONL, EEE and YAT drafted the first version of the manuscript. All authors critically reviewed and approved the final manuscript.

\section{FUNDING STATEMENT}

The work of YAT and EEE was supported by the Russian Foundation for Basic Research (project 19-01500151) and by the Ministry of Education and Science of the RF via the Institute of Cytology and Genetics SB RAS (project number 0259-2021-0009 / AAAA-A17-117092070032-4). The work of ONL and YSA was supported by the Russian Ministry of Science and Education under the 5-100 Excellence Programme.

\section{COMPETING INTERESTS STATEMENT}

YSA is a co-owner of Maatschap PolyOmica and PolyKnomics BV, private organizations, providing services, research and development in the field of quantitative and computational genomics.

Data statement section: Prepublication history for this paper is available online. To view these files, please visit the journal online.

\section{REFERENCES}

1. Berg AJ, Ahmadje U, Jayanna HH, Trégouët $P$, Sanville $P$, Kapoor V. The prevalence of lumbar disc degeneration in symptomatic younger patients: A study of MRI scans. J Clin Orthop Trauma. 2020;11(5):932-6.

2. Brinjikji W, Luetmer PH, Comstock B, Bresnahan BW, Chen LE, Deyo RA, Halabi S, Turner JA, Avins AL, James K, Wald JT, Kallmes DF JJ. Systematic Literature Review of Imaging Features of 
medRxiv preprint doi: https://doi.org/10.1101/2021.03.07.21253070; this version posted March 9, 2021. The copyright holder for this preprint (which was not certified by peer review) is the author/funder, who has granted medRxiv a license to display the preprint in perpetuity.

It is made available under a CC-BY-NC-ND 4.0 International license .

Spinal Degeneration in Asymptomatic Populations. AJNR Am J Neuroradiol. 2015;36(4):811-6.

3. Kos N, Gradisnik L, Velnar T. A Brief Review of the Degenerative Intervertebral Disc Disease. 2019;73(6):421-4.

4. Cheung KMC, Karppinen J, Chan D, Ho DWH, Song YQ, Sham P, et al. Prevalence and pattern of lumbar magnetic resonance imaging changes in a population study of one thousand forty-three individuals. Spine (Phila Pa 1976). 2009;34(9):934-40.

5. Matsumoto M, Okada E, Toyama Y, Fujiwara H, Momoshima S, Takahata T. Tandem age-related lumbar and cervical intervertebral disc changes in asymptomatic subjects. Eur Spine J. 2013;22(4):708-13.

6. Teraguchi M, Yoshimura N, Hashizume H, Muraki S, Yamada H, Oka H, et al. The association of combination of disc degeneration, end plate signal change, and Schmorl node with low back pain in a large population study: The Wakayama Spine Study. Spine J [Internet]. 2015;15(4):622-8. Available from: http://dx.doi.org/10.1016/j.spinee.2014.11.012

7. Jensen RK, Jensen TS, Koes B, Hartvigsen J. Prevalence of lumbar spinal stenosis in general and clinical populations: a systematic review and meta-analysis. Eur Spine J [Internet]. 2020;(0123456789). Available from: https://doi.org/10.1007/s00586-020-06339-1

8. Brinjikji W, Diehn FE, Jarvik JG, Carr CM, Kallmes DF, Murad MH, et al. MRI findings of disc degeneration are more prevalent in adults with low back pain than in asymptomatic controls: A systematic review and meta-analysis. Am J Neuroradiol. 2015;36(12):2394-9.

9. Oichi T, Taniguchi $\mathrm{Y}$, Oshima $\mathrm{Y}$, Tanaka S, Saito T. Pathomechanism of intervertebral disc degeneration. JOR SPINE. 2020;3(1):1-9.

10. Maher C, Underwood M, Buchbinder R. Non-specific low back pain. Lancet. 2017;389(10070):736-47.

11. Middendorp M, Vogl TJ, Kollias K, Kafchitsas K, Khan MF, Maataoui A. Association between intervertebral disc degeneration and the Oswestry Disability Index. J Back Musculoskelet Rehabil. 2017;30(4):819-23.

12. Teraguchi M, Yoshimura N, Hashizume H, Muraki S, Yamada H, Minamide A, et al. Prevalence and distribution of intervertebral disc degeneration over the entire spine in a population-based cohort: The Wakayama Spine Study. Osteoarthr Cartil [Internet]. 2014;22(1):104-10. Available from: http://dx.doi.org/10.1016/j.joca.2013.10.019

13. Oh CH, Yoon SH. Whole Spine Disc Degeneration Survey according to the Ages and Sex Using Pfirrmann Disc Degeneration Grades. Korean J Spine. 2018;14(4):148-54.

14. Sääksjärvi S, Kerttula L, Luoma K, Paajanen H, Waris E. Disc Degeneration of Young Low Back Pain Patients: A Prospective 30-year Follow-up MRI Study. Spine (Phila Pa 1976). 2020;45(19):1341-7.

15. Teraguchi M, Yoshimura N, Hashizume H, Yamada H, Oka H, Minamide A, et al. Progression, incidence, and risk factors for intervertebral disc degeneration in a longitudinal populationbased cohort: the Wakayama Spine Study [Internet]. Vol. 25, Osteoarthritis and Cartilage. Elsevier Ltd; 2017. 1122-1131 p. Available from: http://dx.doi.org/10.1016/j.joca.2017.01.001

16. Kadow T, Sowa G, Vo N, Kang JD. Molecular Basis of Intervertebral Disc Degeneration and Herniations: What Are the Important Translational Questions? Clin Orthop Relat Res [Internet]. 2015;473(6):1903-12. Available from: http://dx.doi.org/10.1007/s11999-014-3774-8

17. Williams FMK, Sambrook PN. Neck and back pain and intervertebral disc degeneration: Role of occupational factors. Best Pract Res Clin Rheumatol [Internet]. 2011;25(1):69-79. Available 
medRxiv preprint doi: https://doi.org/10.1101/2021.03.07.21253070; this version posted March 9, 2021. The copyright holder for this preprint (which was not certified by peer review) is the author/funder, who has granted medRxiv a license to display the preprint in perpetuity.

It is made available under a CC-BY-NC-ND 4.0 International license .

from: http://dx.doi.org/10.1016/j.berh.2011.01.007

18. Xiao L, Ni C, Shi J, Wang Z, Wang S, Zhang J, et al. Analysis of correlation between vertebral endplate change and lumbar disc degeneration. Med Sci Monit. 2017;23:4932-8.

19. Jarman JP, Arpinar VE, Baruah D, Klein AP, Maiman DJ, Tugan Muftuler L. Intervertebral disc height loss demonstrates the threshold of major pathological changes during degeneration. Eur Spine J. 2015;24(9):1944-50.

20. Desmoulin GT, Pradhan V, Milner TE. Mechanical Aspects of Intervertebral Disc Injury and Implications on Biomechanics. Spine (Phila Pa 1976). 2020;45(8):E457-64.

21. Otluoğlu GD, Konya $D$, Toktas $Z O$. The influence of mechanic factors idisc degeneration disease as a determinant for surgical indication. Neurospine. 2020;17(1):215-20.

22. Dragsbæk L, Kjaer $P$, Hancock $M$, Jensen TS. An exploratory study of different definitions and thresholds for lumbar disc degeneration assessed by MRI and their associations with low back pain using data from a cohort study of a general population. BMC Musculoskelet Disord. 2020;21(1):1-11.

23. Navone S, Marfia G, Giannoni A, Beretta M, Guarnaccia L, Gualtierotti R, et al. Inflammatory mediators and signalling pathways controlling intervertebral disc degeneration. Histol Histopathol. 2017;32(6):523-42.

24. Feng $\mathrm{C}$, Liu $\mathrm{H}$, Yang $\mathrm{M}$, Zhang $\mathrm{Y}$, Huang B, Zhou Y. Disc cell senescence in intervertebral disc degeneration: Causes and molecular pathways. Cell Cycle [Internet]. 2016;15(13):1674-84. Available from: http://dx.doi.org/10.1080/15384101.2016.1152433

25. Chen WK, Yu XH, Yang W, Wang C, He WS, Yan YG, et al. IncRNAs: novel players in intervertebral disc degeneration and osteoarthritis. Cell Prolif. 2017;50(1):1-12.

26. Munir S, Rade M, Määttä JH, Freidin MB, Williams FMK. Intervertebral Disc Biology: Genetic Basis of Disc Degeneration. Curr Mol Biol Reports. 2018;4(4):143-50.

27. Kawaguchi Y. Genetic background of degenerative disc disease in the lumbar spine. Spine Surg Relat Res. 2018;2(2):98-112.

28. Riester SM, Lin $\mathrm{Y}$, Wang $\mathrm{W}$, Cong L, Ali AM, Krauss W, et al. RNA sequencing identifies gene regulatory networks controlling extracellular matrix synthesis in intervertebral disk tissues. J Orthop Res. 2019;36(5):1356-69.

29. Kazezian Z, Gawri R, Haglund L, Ouellet J, Mwale F, Tarrant F, et al. Gene Expression Profiling Identifies Interferon Signalling Molecules and IGFBP3 in Human Degenerative Annulus Fibrosus. Sci Rep [Internet]. 2015;5(September):1-13. Available from: http://dx.doi.org/10.1038/srep15662

30. Sherafatian M, Abdollahpour HR, Ghaffarpasand F, Yaghmaei S, Azadegan M, Heidari M. MicroRNA Expression Profiles, Target Genes, and Pathways in Intervertebral Disk Degeneration: A Meta-Analysis of 3 Microarray Studies. World Neurosurg [Internet]. 2019;126:389-97. Available from: https://doi.org/10.1016/j.wneu.2019.03.120

31. Sarath Babu N, Krishnan S, Brahmendra Swamy C V., Venkata Subbaiah GP, Gurava Reddy A V., Idris MM. Quantitative proteomic analysis of normal and degenerated human intervertebral disc. Spine J [Internet]. 2016;16(8):989-1000. Available from: http://dx.doi.org/10.1016/j.spinee.2016.03.051

32. Ye D, Liang $W$, Dai L, Zhou L, Yao Y, Zhong $X$, et al. Comparative and quantitative proteomic analysis of normal and degenerated human annulus fibrosus cells. Clin Exp Pharmacol Physiol. 2015;42(5):530-6. 
medRxiv preprint doi: https://doi.org/10.1101/2021.03.07.21253070; this version posted March 9, 2021. The copyright holder for this preprint (which was not certified by peer review) is the author/funder, who has granted medRxiv a license to display the preprint in perpetuity.

It is made available under a CC-BY-NC-ND 4.0 International license .

33. Yee A, Lam MPY, Tam V, Chan WCW, Chu IK, Cheah KSE, et al. Fibrotic-like changes in degenerate human intervertebral discs revealed by quantitative proteomic analysis. Osteoarthr Cartil [Internet]. 2016;24(3):503-13. Available from: http://dx.doi.org/10.1016/j.joca.2015.09.020

34. Eskola PJ, Lemmelä S, Kjaer P, Solovieva S, Männikkö M, Tommerup N, et al. Genetic Association Studies in Lumbar Disc Degeneration: A Systematic Review. PLoS One. 2012;7(11).

35. Williams FMK, Bansal AT, Van Meurs JB, Bell JT, Meulenbelt I, Suri P, et al. Novel genetic variants associated with lumbar disc degeneration in northern Europeans: A meta-analysis of 4600 subjects. Ann Rheum Dis. 2013;72(7):1141-8.

36. Song YQ, Karasugi T, Cheung KMC, Chiba K, Ho DWH, Miyake A, et al. Lumbar disc degeneration is linked to a carbohydrate sulfotransferase 3 variant. J Clin Invest. 2013;123(11):4909-17.

37. Zhang YG, Guo X, Sun Z, Jia G, Xu P, Wang S. Gene expression profiles of disc tissues and peripheral blood mononuclear cells from patients with degenerative discs. J Bone Miner Metab. 2010;28(2):209-19.

38. Wang Y, Dai G, Wang L, Shang F, Jiang L, Li S, et al. Identification of Key Genes Potentially Related to Intervertebral Disk Degeneration by Microarray Analysis. Genet Test Mol Biomarkers. 2019;23(9):610-7.

39. Pacholczyk-Sienicka B, Radek M, Radek A, Jankowski S. Characterization of metabolites determined by means of $1 \mathrm{H}$ HR MAS NMR in intervertebral disc degeneration. Magn Reson Mater Physics, Biol Med. 2015;28(2):173-83.

40. Xu C, Luo S, Wei L, Wu H, Gu W, Zhou W, et al. Integrated transcriptome and proteome analyses identify novel regulatory network of nucleus pulposus cells in intervertebral disc degeneration. BMC Med Genomics. 2021;14(1):1-12.

41. Pfirrmann CWA, Metzdorf A, Zanetti M, Hodler J, Boos N. Magnetic Resonance Classification of Lumbar Intervertebral Disc Degeneration. 2001;26(17):1873-8.

42. Chen Y, Bao J, Yan Q, Wu C, Yang H, Zou J. Distribution of Modic changes in patients with low back pain and its related factors. Eur J Med Res [Internet]. 2019;24(1):1-9. Available from: https://doi.org/10.1186/s40001-019-0393-6

43. Rajasekaran S, Venkatadass K, Naresh Babu J, Ganesh K, Shetty AP. Pharmacological enhancement of disc diffusion and differentiation of healthy, ageing and degenerated discs: Results from in-vivo serial post-contrast MRI studies in 365 human lumbar discs. Eur Spine J [Internet]. 2008;17(5):626-43. Available from: doi: 10.1007/s00586-008-0645-6

44. Sambrook PN, MacGregor AJ, Spector TD. Genetic influences on cervical and lumbar disc degeneration: A magnetic resonance imaging study in twins. Arthritis Rheum. 1999;42(2):36672.

45. Collins $\mathrm{S}$, Moore R, McQuay H. The visual analogue pain intensity scale: what is moderate pain in millimetres? Pain. 1997;72(1-2):95-7.

46. Fairbank, J.C. Pynsent PB. The Oswestry Disability Index. Spine (Phila Pa 1976). 2000;Nov $15 ; 25(22): 2940-52$.

47. Cherepanov EA. Russian version of the oswestry disability index: cross-cultural adaptation and validity. Hir pozvonočnika (Spine Surgery). 2009;0(3):093-8.

48. McCarthy S, Das S, Kretzschmar W, Delaneau O, Wood A, Teumer A, et al. A reference panel of 64,976 haplotypes for genotype imputation. Nat Genet. 2016;48(10):1279-83.

49. Trbojević Akmačić I, Ugrina I, Štambuk J, Gudelj I, Vučković F, Lauc G, et al. High-throughput 
medRxiv preprint doi: https://doi.org/10.1101/2021.03.07.21253070; this version posted March 9, 2021. The copyright holder for this preprint (which was not certified by peer review) is the author/funder, who has granted medRxiv a license to display the preprint in perpetuity.

It is made available under a CC-BY-NC-ND 4.0 International license .

glycomics: Optimization of sample preparation. Biochem. 2015;80(7):934-42.

480

481

482

483

484

485

486

487

488

489

490

491

492

493

494

495

496

497

498

499

500

501

502

503

504

505

506

507

508

509

510

511

512

513

514

515

516

517

518

519

520

521

522

50. Momozawa Y, Dmitrieva J, Théâtre E, Deffontaine V, Rahmouni S, Charloteaux B, et al. IBD risk loci are enriched in multigenic regulatory modules encompassing putative causative genes. Nat Commun. 2018;9(1):1-18.

51. Zheng J, Haberland V, Baird D, Walker V, Haycock PC, Hurle MR, et al. Phenome-wide Mendelian randomization mapping the influence of the plasma proteome on complex diseases. Nat Genet [Internet]. 2020;52(10):1122-31. Available from: http://dx.doi.org/10.1038/s41588-020-06826

52. Zhu Z, Zhang F, Hu H, Bakshi A, Robinson MR, Powell JE, et al. Integration of summary data from GWAS and eQTL studies predicts complex trait gene targets. Nat Genet. 2016;48(5):481-7.

53. Ikuno A, Akeda K, Takebayashi SI, Shimaoka M, Okumura K, Sudo A. Genome-wide analysis of DNA methylation profile identifies differentially methylated loci associated with human intervertebral disc degeneration. PLoS One. 2019;14(9):1-20.

54. Dobin A, Davis CA, Schlesinger F, Drenkow J, Zaleski C, Jha S, et al. STAR: Ultrafast universal RNA-seq aligner. Bioinformatics. 2013;29(1):15-21.

55. Robinson MD, McCarthy DJ, Smyth GK. edgeR: A Bioconductor package for differential expression analysis of digital gene expression data. Bioinformatics. 2009;26(1):139-40.

56. Parisien M, Khoury S, Chabot-Doré A-J, Sotocinal SG, Slade GD, Smith SB, et al. Effect of Human Genetic Variability on Gene Expression in Dorsal Root Ganglia and Association with Pain Phenotypes. Cell Rep [Internet]. 2017 May;19(9):1940-52. Available from: https://linkinghub.elsevier.com/retrieve/pii/S2211124717306435

57. Krutko A V., Sanginov AJ, Baykov ES. Predictors of Treatment Success Following Limited Discectomy With Annular Closure for Lumbar Disc Herniation. Int J Spine Surg. 2020;14(1):3845.

58. Leonova O, Baykov E, Sanginov A, Krutko A. Cervical Disc Degeneration and Vertebral Endplate Defects After the Fused Operation. Spine (Phila Pa 1976) [Internet]. 2021;(Feb 16):Ahead of Print. Available from: doi: 10.1097/BRS.0000000000004007

59. Freidin MB, Tsepilov YA, Palmer M, Karssen LC, Suri P, Aulchenko YS, et al. Insight into the genetic architecture of back pain and its risk factors from a study of 509,000 individuals. Loos RJF, editor. Pain [Internet]. 2019 Jun 6;160(6):1361-73. Available from: https://dx.plos.org/10.1371/journal.pgen.1007601

60. Elgaeva EE, Tsepilov Y, Freidin MB, Williams FMK, Aulchenko Y, Suri P. ISSLS Prize in Clinical Science 2020. Examining causal effects of body mass index on back pain: a Mendelian randomization study. Eur Spine J [Internet]. 2020 Apr 3;29(4):686-91. Available from: http://link.springer.com/10.1007/s00586-019-06224-6

61. Freidin MB, Tsepilov YA, Stanaway IB, Meng W, Hayward C, Smith BH, et al. Sex- and age-specific genetic analysis of chronic back pain. Pain [Internet]. 2020 Sep 30;Publish Ah. Available from: https://journals.Iww.com/10.1097/j.pain.0000000000002100

62. Tsepilov YA, Sharapov SZ, Zaytseva OO, Krumsek J, Prehn C, Adamski J, et al. A network-based conditional genetic association analysis of the human metabolome. Gigascience. 2018;7(12):111.

63. Sharapov SZ, Tsepilov YA, Klaric L, Mangino M, Thareja G, Shadrina AS, et al. Defining the genetic control of human blood plasma $\mathrm{N}$-glycome using genome-wide association study. Hum $\mathrm{Mol}$ Genet. 2019;28(12):2062-77. 
medRxiv preprint doi: https://doi.org/10.1101/2021.03.07.21253070; this version posted March 9, 2021. The copyright holder for this preprint (which was not certified by peer review) is the author/funder, who has granted medRxiv a license to display the preprint in perpetuity.

It is made available under a CC-BY-NC-ND 4.0 International license .

64. Riyazi N, Meulenbelt I, Kroon HM, Ronday KH, Hellio Le Graverand MP, Rosendaal FR, et al. Evidence for familial aggregation of hand, hip, and spine but not knee osteoarthritis in siblings with multiple joint involvement: The GARP study. Ann Rheum Dis. 2005;64(3):438-43.

65. Yau MS, Demissie S, Zhou Y, Anderson DE, Amanda L. Correlations With Other Spine Traits : The Framingham Study. 2016;31(12):2077-84.

66. Allegri $M$, De Gregori $M$, Minella CE, Klersy C, Wang $W$, Sim $M$, et al. Omics' biomarkers associated with chronic low back pain: Protocol of a retrospective longitudinal study. BMJ Open. 2016;6(10):1-8.

67. Urrutia J, Besa P, Campos $M$, Cikutovic $P$, Cabezon M, Molina $M$, et al. The Pfirrmann classification of lumbar intervertebral disc degeneration: an independent inter- and intraobserver agreement assessment. Eur Spine J. 2016;25(9):2728-33. 